\title{
Ralph Waldo Emerson and William James as Public Philosophers
}

\author{
By \\ George CotKin*
}

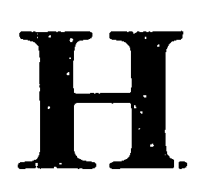

ARVARD philosophers, wrote George Santayana with no small degree of derision, often functioned as "clergymen without a church .... at once genuine philosophers and popular professors." They were men forced by their discipline to describe reality effectively yet proscribed by that same status to make it palatable "to certain preconceived human desires."1

Though a secular cleric without a church, the public philosopher did stand upon the respected platform of the Lyceum. From this vantage point he surveyed America's problems and sought to soothe the troubled minds of the public. From the 1830 s until the first decade of the twentieth century, Americans were in continual need of comfort and guidance; as John Higham phrased it, the nation was moving from boundlessness to consolidation with each shift engendering a particular set of difficulties. ${ }^{2}$ During this era the United States was in a constant state of change and convulsion attributable to industrialization, immigration, class conflict, urbarization, religious controversy, the Civil War as d imperial expansion. The function or callir. $g$ of the public philosopher was to address these changes in a non-partisan manner, to engage the issues in terms of the perennial problems of social and ethical philosophy and to devise answers compatible with the preconceived notions of his listeners. The public philosopher, then, sought to

-The author, Associate Professor of History at California Polytechnic State University, wislies to thank James Hoopes and Bruce Kuklick for their comments on this essay, as well as Houghton Library, Harvard University, and Mr. Alexander James for permission to quote from the James Family Papers. David Hollinger and Robert Rydell have offered the author guidance and insight on William James for a number of years.

'Quoted from Bruce Kuklick, The Rise of American Philosophy: Cambridge, Massachusetts, 1860-1930 (New Haven, 1977), 307. Compare George Santayana, Character and Opinion in the United States (London, 1920), 43, 61-62.

2John Higham, From Boundlessness to Consolidation: The Transformation of American Culture, 1848-1860 (Ann Arbor, 1969); T. J. J ackson Lears, No Place of Grace: Antimodernism and the Transformation of American Culture, 1880-1920 (New York, 1981). 
illuminate, define and solve the problems of the era without recourse to a rigorous and abstract mode of explication. Yet, the best of the public philosophers sought to confront. America's problems through a systematic application of their general philosophical precepts.

The need for a philosophy that would celebrate the individual and also recognize the centrality of the social self was more evident as America became increasingly fragmented in the nineteenth century. The older moral philosophy of the Scottish Common Sense school with its emphasis upon abstract concepts of duty, morality, tradition and truth did not seem adaptable to the volume and magnitude of change: moral certainties, as preached by university presidents such as Francis Wayland, James Walker, and John D. Gros, sounded more hollow and dated with each successive year. The professionalization of philosophy boded well for systematic thought but proved to be too specialized and arcane for public consumption. ${ }^{3}$

Into the space between the older school of moral philosophy and the newer school of professional philosophy stepped Ralph Waldo Emerson and William James, America's most distinguished and vibrant public philosophers. ${ }^{4}$ Both men practiced their craft before professionalization

${ }^{3}$ For discussions of these academic moral philosophers and the role of the clergy in this era, see Wilson Smith, Professors and Public Ethics: Siudies of Northern Moral Philosophers before the Civil War (Ithaca, N.Y., 1956); Donald M. Scott, From Office to Profession: The New England Ministry, 1750-1850(Philadelphia, 1978); D. H. Meyer, The Instructed Conscience: The Shaping of the American National Ethic (Philadelphia, 1972). J. David Hoeveler, Jr., James McCosh and the Scottish Intellectual Tradition: From Glasgow to Princeton (Princeton, 1981), presents a favorable account of one moral philosopher's receptiveness to change. For a contemporary critique of the "old-style" philosophizing, see G. Stanley Hall, "Philosophy in the United States," Mind 4 (January 18,9): 89-105.

'Kuklick is critical of the quality of public philosophy while also recognizing its centrality to American culture. He dismisses public philosophy as an uninteresting and unoriginal form of philosophy. This paper seeks not to judge the quality of public philosophy but to explicate its cultural context and message while relating it to the general intellectual system of each thinker. See Kuklick, Rise, 46-62, 291-314. See also Kuklick, "Studying the History of American Philosophy," Transactions of tice Charles S. Peirce Society 18 (Winter 1982): 18-33, and "The Changing Character of Philosophizing in America," Philosophical Forum 10 (Fall 1978): 4-13.

This essay does not attempt to evaluate James' indebtedness to or revision of Emerson; that is a subject for an cssay on influence and tradition. Guidance on the Emersonian legacy in American thought and James' reworking of it may be found in: Frank Lentricchia, "On the Ideologies of Modernism, 1890-1913: The Example of William James" in Reconstructing American Literary History, ed. Sacvan Bercovitch (Cambridge, Mass., 1986), 229-42; Harold Bloom, Agon: Towards a Theory of Revisionism (Oxford and New York, 1982), esp. 39-42, 145-78. Also, Frederic I. Carpenter, "Points of Comparison Between Emerson and William James," New England Quarierly 2 (July 1929): 458-74; F. T. Brown, "William James and the Philosophy of Emerson," Mcthodist Review 76 (September 1904): 747-56. 
had clarified the boundary lines between popular and professional philosophy. Public philosophers such as Emerson and James believed the division between popular and elite culture unnecessary and unwanted, a schism to be transcended. Middle-class Americans welcomed the orphic pronouncements of Emerson and the pragmatic maxims of James as readily as discussions of phrenology, mesmerism or exotic lands. ${ }^{5}$ Favorable public response brought Emerson and James muchneeded income for the support of their families, with the added advantage of furnishing them with large audiences. For the prophet and seer Emerson, a man desperately in need of an audience, the public lecture was a natural forum for ihe proselytizing of his doctrine of "the infinitude of the private man." The lecturer, in Emerson's eyes, was a type of Napoleon, a man who conquered his audience. ${ }^{6}$

The discourse of public philosophy in America, as practiced by Emerson and James, evolved from what F. O. Matthiessen called "the double-tendency towards standardization and anarchy."7 In their respective public philosophies, Emerson and James addressed this double tendency in terms of the relationship between self and society. While the double tendency remained constant in the work of Emerson and James, their solutions to it differed because they were shaped by

${ }^{5}$ On the holism of American culture in this era, see Lawrence Levine, "William Shakespeare and the American People: A Study in Cultural Transformation," American Historical Review 89 (February 1984): 34-66. On the problems of intellectuals and the development of academic institutions, see Burton J. Bledstein, The Culture of Professionalism: The Middle Class and the Development of Higher Educalion in America (New York, 1976); Thomas L. Haskell, The Emergence of Professional Social Science: The American Social Science Association and the Nineleenth-Century Crisis of Authority (Urbana, Ill., 1977).

${ }^{6}$ William H. Gilman et al., eds., The Journals and Miscellaneous Notebooks of Ralph Waldo Emerson, 16 vols. (Cambridge, 1960-1982), 9:243; 7:342. Also, Daniel B. Shea, "Emerson and the American Metamorphosis," in Emerson: Prophecy, Metamorphosis and Influence, ed. Daniel Levin (New York, 1975), 49; David Robinson, Apostle of Culture: Emerson as Preacher and Lecturer (Philadelphia, 1982), 4, 145. On William James' financial difficulties, see Gay Wilson Allen, William James: A Biography (New York, 1967), 369-70, 383-84; Henry Jaines, ed. The Letters of William James [LWJ], 2 vols. (Boston, 1920), 2:4-5. James' criticisms of public lecturing were well-known and often repeated. See, for example, W. James to Henry James, 30 November 1907; W. James to William James, Jr., 2 January 1907, James Family Papers [JFP], Houghton Library, Harvard University. For a more favorable impression o! James' successes andi mission as a lecturer, see W. James, Memories and Studies (New York, 1911), 33. On the benefits of lecturing, see, for example, W. James to M. M. James, 30 January 1907; W. James to Alice G. James, 5 February 1907, JFP. David $A$. Hollinger discusses James' role in urging his listeners to think and act in "William James and the Culture of Inquiry," Michigan Quarterly Review 20 (Summer 1981): 264-83; and "The Problem of Pragmatism in American History," Journal of American Hislory 67 (June 1980): 97-99.

'F. O. Matthiessen, American Renaissance; Art and Expression in the Age of Emerson and Whitman (New York, 1968), 66-67. 
specific historical situations. Emerson's representative and highly popular lecture "Social Aims" (1864) appeared in an era of expansiveness and fragmentation; th: arefore it veers toward the social requirements and responsibilties of the citizen, demanding equilibrium between self and society. "On a Certain Blindness in Human Beings" (ca. 1898), a lecture written by James in a period of increasing institutional consolidation and a narrowing of individual differences, spoke for the diversity of perception while recognizing the dangers of the Imperial Self. ${ }^{9}$

The theme of both essays concerned the relationship between self and society, but each essay furnished different societal recommendations. The boundlessness of the Imperial Self, the "infinitude of the private man" which some have viewed as central to Emerson, is understated in "Social Aims." 10 In its place is a doctrine of self-control, the self mediated by society and manners. The self, while no longer imperial, remains woven of royal cloth; Emerson could never fully disrobe his individualism. James' "On a Certain Blindness" warns against the dominating ego, the self that seeks to judge and control others according to its own standards and tastes. He rejects the imperialism of the individual ego by pointing out the realities of other egos. The lecture is, in essence, a plea for the essential Jamesian themes of openness, acceptance and pluralism.

Although Emerson's and James' recommendations reflected shifts in American society, both talks were occasioned by particular conflicts: the Civil War for Emerson and American expansionism and the Spanish-American $W$ ar for James. Neither lalk, however, could explicitly confront these momentous issues. The public lecture demanded a specific form of address, one couched in the uniformities of perennial philosophical and social problems. The etiquette of the popular lecture was precise, and Emerson and James were wary about transgressing its boundaries. Yet both managed, by working within the parameters of the popular lecture, to confront in implicit, though nonetheless important, fashion the specific and highiy controversial issues of their times. ${ }^{11}$

8Emerson's "Social Aims" is in his Letters and Social Aims in Works, ed. Edward Waldo Emerson, 12 vols. (Boston, 1903-1904), 8:77-107. Hereafter, citations to this talk will appear in the text.

'James' "On a Certain Blindness in Human Beings" was collected in his Talks to Teachers on Psychology: The Works of William James (Cambridge, Mass., 1983), 132-49. Hereafter, citations to this talk will appear in the text.

${ }^{10}$ The strongest statement of this is in Quentin Anderson, The Imperial Self: An Essay in American Literary and Cultural History (New York, 1971). Also see Maurice Gomaud, "Emerson and the Imperial Sclf: A European Critique," in Levin, Emerson, 107-28.

"For an excellent discussion of the Lyceum movement and the popular lecture, see Scott, "The Popular Lecture and the Creation of a Public in Mid-Nineteenth Century 
In "Social Aims" and "On a Certain Blindness in Human Beings," Emerson and James spoke directly to middle-class America. Analysts have often ignored these iectures because they are seen to lack originality, philosophical sophistication, or import. Although Stephen Whicher, Harold Bloom and Stanley Cavell have seriously examined Emerson's later writings, especially the seminal essay "Fate" in The Conduct of Life (1859), scholars generally disparage the work concluded by Emerson in the 1850s and after. Some suggest Emerson had by then spent his creative force. ${ }^{12}$ James' "On A Certain Blindness," and his other lectures on social issues, are dismissed by some as popular and trite, lacking in philosophical significance and interest. ${ }^{13}$

Yet Emerson's "Social Aims" and James' "On a Certain Blindness" are important representative works, lectures that neatly summarize the essential messages of their authors, and capture their author's mature moral philosophies. In addition, these lectures were highly popular with audiences and had a special place reserved for them in their authors' affections. "Social Aims" was the most popular of Emerson's lectures. According to William Charvat, Emerson delivered it over seventy times in fifteen states between 1864 and 1872 . This single lecture earnied Emerson as much financial reward as one of his better-known

America, "Jouınal of American History 66 (March 1980): 781 -809; Scott, "The Democratization of Knowledge in America, 1840-1880" (paper presented to the annual meeting of the Organization of American Historians, Los Angeles, 1984). Less interpretively sophisticated but still useful examinations of the Lyceum are: Carl Bode, The American Lyceum: Town Meeting of the Mind (Carbondale, Ill., 1968); Carl David Mead, Yankee Eloquence in the Middle West: The Ohio Lyceum, 1850-1870 (East Lansing, Mich., 1951). Revealing conternporary acrounts of the Lyceum are: Harmon D. Jenkins, "The American Lyceum," Presbyterian and Reformed Review 7 (January 1897): 46-57; Thomas Wentworth Higginson, "The American Lecture System," MacMillan's Magazine 18 (May 1868): 48-56.

12Stanley Cavell, "Genteel Responses to Kant? In Emerson's 'Fate' and in Coleridge's 'Biographia Literaria,"' Raritan 3 (Fall 1983), esp. 42-46; Bloom, Agon; Stephen E. Whicher, Freedom and Fate: An Inner Life of Ralph Waldo Emerson (Philadelphia, 1953); J. Russell Reaver, "Emerson's Focus in The Conduct of Life," South Allantic Bulletin 45 (November 1980): 78-89; Richard Lee Francis, "Necessitated Freedom: Emerson's The Conduct of Life" in Studies in the American Renaissance 1980, ed. Joel Myexson (Boston, 1980), 73-89; Joel Porte, Representative Man: Ralph Waldo Emerson in His Time (New York, 1979), 279-82.

${ }^{15}$ The strongest critique of James as a public figure is offered in George R. Garrison and Edward H. Madden, "William James-Warts and All," American Quarlerly 29 (Summer 1977): 207-21. Also critical of Jamesian social philosophy are William E. Leverette, Jr., "Simple Living and the Patrician Academic: The Case of William James," Journal of American Culture 6 (Winter 1983): 36-43; M. C. Otto, "On a Certain Blindness in William James," Ethics 53 (April 1943): 184-91. More favorable, although still critical of James, is James Camplell, "William James and the Ethics of Fulfillment," Transactions of the Charles S. Peirce Society 17 (Summer 1981): 224-40. 
books. ${ }^{14}$ James remarked that, "On a Certain Blindness" was "better loved by me than any of my other productions." The popularity of the lecture was attested further when Henry Holt and Company published it in 1900, along with James' companion piece "What Makes a Life Significant," as a separate volume entitled On Some of Life's Ideals. ${ }^{15}$

Emerson's "Social Aims," as the title suggests, dissects the social inclinations, the presentation of the self in society. Although speaking in what Melville characterized as the age of the confidence man, a period when deceit had become synonymous with the rise of democracy and the common man, Emerson appears unconcerned with the masks that people wear. ${ }^{16} \mathrm{~A}$ person's true character and intentions can never be hidden. According to Emerson, all masks are easily rendered transparent. Clothes, which standardize appearance and present the individual to others, cannot, says Emerson, cover the qualities of a mind or the strength or weakness of a personality. A man blessed with manners "may dress roughly and carelessly," arid still be respected by others. Yet clothes do have much to offer, for proper attire can help to elevate an individual to a higher level of self respect. Such a new sense of self is illusory unless the newly clothed individual directs his actions to agree with his acquired sartorial grace (87-88).

Manners, behavior and etiquette, Emerson lectured his audience, bring forth the best and lessen the worst in an individual. They are the internal directives that render the external compulsion of institutions superfluous. As internal directives they control the buoyant ego and redirect its energies. Powerful leaders and speakers are those whose control over their passions is strongest and most assured. A few wellchosen and pointed words, spoken with conviction and without the hurry of the emotions, will carry the day. The rule to success, then, is no longer simply "self-reliance"; it is now "self-control." All of us, Emerson warns, contain "a noisy, sensual savage" whose will must be suppressed if one is to "turn all his strength to beauty" $(100,86)$. Control and direction, rather than expansiveness and freedom, become the predominant themes of Emerson's late lecture, "Social Aims."

"William Charvat, Emerson's American Lecture Engagements: A Chronological List (New York, 1961), !0. The popularity of the themes contained in "Social Aims" to both Emerson and his audiences is further demonstrated by recognizing its affinities with his lecture, "Behavior" in The Conduct of Life (1860), Works 6:167-97.

15James, Talks to Teachers, 256, 271.

${ }^{16}$ On the confidence man theme, see Karen Halttunen, Confidence Men and Painted Women: A Study of Middle-Class Culture in America 1830-1870 (New Haven, 1982), csp. 198-210; Michael Paul Rogin, Subversive Genealogy: The Politics and Art of Herman Melville (New York, 1983), 27. 
At once aloof and colloquial in style, E.merson in "Social Aims" sounds almost like a purveyor of success proverbs in the tradition of Benjamin Franklin and later Orison Marden, Horatio Alger and Russell Conwell. ${ }^{17} \mathrm{His}$ middle-class listeners are told to control their tempers lest emotional outbursts diminish their eloquence; they are admonished, in no uncertain terms, to seek out leaders who are "wise, temperate, and heroic." Sounding again like a merchant of the gospel of success, Emerson exults in the recognition that any young man blessed with perseverance can become successful (100). Emerson, of course, does not advocate success in pecuniary terms. Value and wealth are created through knowledge and labor, which must be directed toward spiritual rather than material ends. To be sure, each man needs some income to secure his physical needs and independence, but he need not be materially rich. In a passage which probably ended the lecture, but which Emerson omitted from the published version, he stated that a man must convert his material capital into a spiritual and personal coin of the realm: "Convert yourself into wealth, and you shall buy kings. Sordid calculations convert you into punk and abhorrence" (378-80).

In "Social Aims" Emerson departs most forcefully from his earlier writings when he announces that the journey to spiritual wealth is not traveled alone; "Social Aims" is a paean to the social aspects of existence, to the necessity and value of social interdourse and duty; the individual is not self-sufficient. The Imperial Self once predominant in Emerson has been quieted. From our earliest days, Emerson posits, we are social beings. The young child is carefully and lovingly nurtured in the value of manners by adoring relatives. Friendship becomes,sustenance for the individual; it helps him to achieve more, to grow and to be elevated to "see the zenith above and the nadir under us." The transparent eyeball in Nature, bathed in the sunlight of the individual ego, remains but is now illuminated by the strong rays of sociability (91-92).

In his "American Scholar" address of 1837, Emerson eloquently described his "man thinking" as an intense individualist. While the true scholar was not a bookworm chained to his study, he remained nonethcless a person alone, a sort of Third Estate "with the world and the soul." "Social Aims" moves the scholar from the sanctity of his own self into a conversation with mankind. The greatness of "man thinking" can only be realized through intellectual companionship. The scholar is challenged by men of manners whose posture and intellect help him to grow (91). The avenue of conversation is widened from man and nature to man and man. Emerson speaks in praise of conversation, noting that the social graces and conversational qualities of women are

\footnotetext{
${ }^{17}$ On these adherents to the Gospel of Success, see John G. Cawelti, Apostles of the Self-Made Man: Changing Concepts of Success in America (Chicago, 1965), esp. 86-98.
} 
without par. He singles out Madame de Staël for her bon mots and wisdom. Conversation delights and instructs, Emerson lectures, it "fills all gaps, supplies all deficiencies" (92-95).

Emerson was and remained essentially a dialectical thinker. While much of "Social Aims" spoke to the conceits and vanities of his smalltown, middle-class audience, the lecture was circular: each point came back upon itself with an admonition or warning that whole-hearted acceptance was misguided. "Social Aims" praises friendship, sociability and manners, all values which Emerscon finds worthy. Yet he also warns in the essay that their privileged status must not come at the expense of the self. Thus, while companionship is wonderful and visitors are to be welcomed by the scholar, they must not be allowed to dominate his time. Friendship is good because it opens us up to others' thought, but it is fraught with danger when conversation between friends becomes petty or indulgent. Intellectual intercourse promises to uplift and elevate but it also introduces the danger of influence. Th is anxiety threatens to force us to "recite other people's opinions." The anxiety of influence, Emerson contends, is avoided when we "stay at home" in our own minds (99).

"Social Aims." fits the renre of public philosophy as it begins with a firm statement of values (while hinting at their problematical nature) and ends on a note of hope and affirmation for the American mission. ${ }^{18}$ This organizational structuring of the essay obviated the difficulties of translating the Emersonian dialectical style of statement, revision and reformulation to the needs and capabilities of his lecture audience. Contradictions and reversals of thought, while still apparent and important, are reduced through the lecture medium to aphorisms and admonitions, all of which are further placed within a reassuring mode followed by a crescendo at the close of the lecture.

"The American Scholar" had opened with a full-throttled call for intellectual independence from foreign styles and sensibilities. "Social Aims" begins by taking to heart foreign criticisms of American manners. Such critiques, Emerson now finds, afford Americans a useful opportunity to examine their values and to strengthen them. The ultimate value of manners, however, remains for Emerson a fixed point. Emerson is fulsome in his praise of manners: "their charm cannot be predicted or overstated." The opening sentences clearly delineate the surest means of acquiring these valued commodities: best of all would be "by living with the well-bred from the start." When that is not possible, then one must seek out and learn from "cultivated society" (79). Society is rendered hierarchical, but it remains accessible through

${ }^{18}$ The theme of the American mission in Emerson's thought is developed in Sacvan Bercovitch, "Emerson the Prophet: Romanticism, Puritanism, and Auto-AmericanBiography," in Levin, Emerson, 1-28. 
democratic striving. Such words were timely and comforting: to Emersun's audiences, described in newspaper reports as the social elites of the towns where Emerson stopped to lecture. ${ }^{19}$

The Emersonian public philosophy found in "Social Aims" culminated in a note of affirmation, hope and inspiration. Presented during the period of the Civil War, the final paragraph of "Social Aims" must have left listeners deeply satisfied. Manners, conversation, labor and even public activity are the basis of society, exclaimed Emerson. While American manners, as he suggested in the opening sentences, may not be perfect, there is a desire for improvement afoot in the land, a melioration which will be continued and perhaps brought to fruition with the next generation. Emerson envisioned an America marked by "intelligence, manly enterprise, good education, virtuous life and elegant manners" (107). His was a vision of strong individuals contained within an equally strong community; the individual in search of himself had now found himself within the structure of community.

William James' "On a Certain Blindness" concerned itself with the same general themes of Emerson's "Social Aims": the relationship of self to society. For Emerson the need was to allow freedom for the self while respecting and accepting the values and demands of society. For James, writing thirty years later, the demands of society had been transformed into a pervasive given. The consolidation of society and its concomitant structures of bureaucracy had become, according to James, the imprisoners of the self. ${ }^{20}$ Society was now, stated James in Emersonian terms, a roadblock which inhibited communing with nature and experiencing transcendental freedom. James agreed wholeheartedly with Emerson's "matchless eloquence" which celebrated the "sovereignty of the living individual," but remained acutely aware of the imperial tendencies of sovereign individuals. In his critique of society, James defined scciety not as a corporate entity but as a conglomeration of independent selves who threatened to impose their individual prejudices and wills on others. It was in this sense, then, that William James grappled with the perennial problem of public philo-

${ }^{19} \mathrm{Brad}$ Luckingham, "The Pioneer Lecturer in the West: A Note on the Appearance of Ralph Waldo Emerson in St. Louis, 1852-1853," Missouri Historical Review 55 (October, 1963): 70-88; C. J. Wasung, "Emerson Comes to Detroit," Michigan History 29 (January: 1945): 59-72; Louise Hastings, "Emerson in Cincinnati," New England Quarterly 11 (September 1938): 443-69.

${ }^{20}$ James' most famous statement of this: "I am against all big organizations as such, national ones first and foremost. ..." It appeared in a letter to Mrs. Henry Whitman, 7 June 1899, LIVJ 2:90. 
sophy. He sought to avoid the domination of society and individualism while sanctioning freedom and sciciability. In Ralph Barton Perry's words, James' moral philosophy was divided between "militant selfassertion" and the demands of society and humanity. ${ }^{21}$

James immediately set the tone of his essay by emphasizing the centrality and vibrancy of feelings as experienced by the individual. What we most feel, what becomes most significant to us, represents for each of us a "vital secret." The specificity of these experiences and their particular character was a theme that James had earlier developed in his Principles of Psychology (1890), when he spoke of sense impressions: "whatever excites and stimulates our interest is real." 22 But within each vital secret lay a set of dangers. The experiences, if secret or deeply experienced only by the individual, were not easily comprehended by others. Another greaier problem was that the imperial nature of our experiences or vital secrets, the belief that our ou'n experiences were supreme, could lead to presumptions on the vaiue of other peoples' experiences (132). James illustrated with the story of a North Carolina squatter who had cleared a small patch of land in a beautiful mountain setting. In creating his farm, he had built a ramshackle house, irregularly planted Indian corn, and constructed a "zigzag rail fence." In James' mind this farmer had desecrated virgin land; the farm was an outrage against beauty. But Jannes soon realized that his vision of beauty, his inner experience of that phenomenon, did not coincide with the squatter who believed that he had achieved a personal victory over the environment and brought the beauties of civilization to the mountains. "In short," James realized, "the clearing which to me was a rnere ugly picture on the retina, was to them a symbol redolent with rnoral memories and sang a very paean of duty, struggle, and success" (134). While James does not consider the likelihood of each person's vision of beauty undermining possible enjoyment by others, he uses this episode to illustrate what he consiclered the pressing problem confronting Ame:icans: a blindness to the experiences and philosophies of other individuals. This was a recurring theme in James' philosophy. As he noted in "The Moral Philosopher and the Moral Life" (1891), it would be better to have chaos "than an order based on any closetphilosopher's rule, even though he were the most enlightened member of his tribe." 23

Beyond pointing out an individual's blind spot toward others, it was necessary to enlighten each individual so that he or she might

${ }^{21} \mathrm{~W}$. James, Memories and Studies, 25. Raljh Barton Perry, The Thought anic Character of William James, 2 vols. (Boston, 1935), 2:280.

${ }^{22}$ W. James, Principles of Psychology: The Works of William James, 2 vols. (Cambridge, Mass., 1981), 2:924.

${ }^{23} \mathrm{~W}$. James, The Will to Believe: The Works of William James (Cambridge, Mass., 1979), 155. 
experience firsthand what James called "the higher vision of an inner significance" (198). This experience was akin to religious conversion and captured what Emerson had described as those moments when we suffuse certain experiences with a reality above all others. The passion exacted by love served as a paradigm of such intense, mystical feelings.

The problem, as James reiterated throughout the essay, was how to experience the feelings of transcendence and bliss great poets and religious converts described. At the heart of our dearth of feelings lay the nature of modern existence. Because we had become such "practical creatures," we paid a price, we experienced a deadening of feelings (138). We had, in effect, distanced ourselves from nature; we had encumbered ourselves with the artificial. Here again James invoked a romantic vision and called upon Emerson for support. Addressing his middleclass audience in direct fashion, James pronounced that "we of the highly educated classes (so called)" have become divorced from nature. We have blinded ourselves to the beauty and power of the common, and hence limited ourselves to the joys of the rare. In sum, we lead unfulfilled lives (146). ${ }^{24}$

James' call for a return to nature and an active existence was, as Jackson Lears has pointed out, typical among Gilded Age intellectuals. ${ }^{25}$ It sometimes took the form of primitivism of the sort James invoked when he guoted a lengthy passage from W. H. Hudson's Idle Days in Patagonia. The excerpt espouses an escape from society to the remote and the solitary. In a place like Patagonia, where silence dominates and one's reveries are never interrupted by the din of modern existence, an individual can experience elation, a "state of intense watchfulness, or alertness." All the senses are heightened, and one feels that "he is in perfect harmony with nature" (148-49). ${ }^{26}$ James' use of Hudson's passages is reminiscent of the transparent eyeball passage of Emerson's Nature where the individual becomes lost in the rhythms of nature. But reveries remain descriptive and James realizes that while they may excite and satisfy, they fa!! to explain how his listeners, modern men and women in an urban, industrial environment, are to transcend their iron cages of everyday existence and exult in "this mysterious sensorial life, with its irrationality" (149).

2James addressed this issue in his essay. "The Energies of Mon" in Essays in Religion and Morality: The Works of William James (Cambridge, Mass., 1982), 129-46. Also, Don Browning, "William James's Philosophy of the Person: The Concept of the Strenuous Life," Zygon 10 (June 1975): 162-74.

2'Lears, No Place of Grace; Leverette, "Simple Living."

${ }^{26}$ James expressed a similar relationship to nature when she showed her more violent side. See his "On Some Mental Effects of Earthquakes" in Memories and Studies, 211. For more on this, see George Cotkin, "William James and the 'Weightless' Nature of Modern Existence," San José Studies 12 (Spring 1986): 7-16. 
In his conclusion, James addresses the demand that public philosophy end on a note of affirmation, hope and guidance. Here he reiterated an introductory theme of his essay: We must be wary of the Imperial Self which desires to announce the "meaninglessness of forms of existence other than our own." In tones which summed up the general tenor of James' entire moral philosophy, he stated that we must "tolerate, respect, and indulge" other modes of existence. The world must not be seen in block terms, it must be viewed pluralistically. Hence James adopted - and called upon his listeners to accept-a laissez-faire policy. We should--philosopher as much as salesman or printer-never believe that any of us possesses the entire truth. This is, of course, a concise and perhaps gross simplification of James' view of truth as a process, as a set of possibilities to be realized rather than a dogma to be possessed. Yet, in a few sentences, he does manage to communicate the essential traits of his pluralistic philosophy: openness, observation and the singularicy of experience. The essay ends, appropriately, with an Emersonian ode to the common. Revelations, feelings of intense understanding of the mysteries and joys of life can be found anywhere, certainly in nature and even in prisons and sickrooms. Emerson's advice in "Social Aims," that each person be himself without imposing on the sanctity of others is echoed in James's closing words. He warns each member of his audience to "be faithful to his own opportunities and make the most of his own blessings [but] without presuming to regulate the rest of the vast field" (149).

Of course, Emerson and James left untouched the knotty problems of how to adjudicate specific economic and ecological disputes between individuals. They left the detailed analysis of such conflicts to political philosophers. This might be coristrued as a lack of seriousness or intellectua! commitment on their part to the solution and explication of the problems, but the mode of discourse demanded this lack of specificity and detailed analysis. In public philosophy one addressed problems in elliptical fashion, not head on with specific references. 'The troubles of the era-the Civil War and the fight against slavery for Emerson, the "labor problem" and nascent American imperialism for James-were not to be broached or exhaustively analyzed within public philosophy. To refer in explicit fashion to such concrete problems, and especially to suggest concrete resolution of those difficulties, would have been too controversial, it would have transformed public philosophy into partisan philosophy. Yet implicit within both "Social Aims" and "On a Certain Blindness" were resporses to the social problems and controversies of their respective eras. Neither lecturer exhibited blindness to the social realities of their time. Moreover, while the primary focus or intention of both Emerson and James in these 
lectures was to address a perennial problem of public philosophy-the relation of self to society-both authors had other intentions as well. As Quentin Skinner and John Dunn might phrase it, Emerson and James implied larger social intentions and political commentary within their utterances, which do not fall outside of "the range of descriptions which the author in principle might have avowed." 27

"Social Aims," a lecture delivered during the closing years of the Civil War, reiterated themes that had become predominant in Emerson's thought in the 1850s as he grew more energetic in his espousal of anti-slavery sentiments. It contains a prescription for troubled times and is also an explanation of Emerson's shift away from the Imperial Self of the 1830s to his more socially anchored self of the 1850s. As George Fredrickson has insightfully remarked, Emerson's transcendentalism changed from a philosophy of contemplation to one of action, action which presupposed social intercourse. But the crucial element in forcing Emerson into the social arena, and of combining the needs of the individual with those of the unit, were the changes forced by his wholehearted support for the Northern effort in the: Civil War. Emerson, the old antinomian, now became more respectful of institutions and discipline, as evidenced by his acceptance of a post as official visitor to West F'oint in 1863. ${ }^{28}$

Nowhere in "Social Aims" does Emerson directly confront the reality of the Civil War, but its presence is silently felt throughout the essay. While Emerson remains disdainful towards institutional coercion, he now ralls for concerted social action and sociability. Self control would restrain the Imperial Self and manners would allow it to function with others in society. The earlier anarchism of Emerson has been rendered anachronistic by the demands of the Civil War. Emerson hoped to demonstrate in "Social Aims" that people could work together, in commor. cause, by internal restraint alone-making institutional constraints unnecessary. Thus "Social Aims" addressed a specific sociai issue but without explicitly appearing to do so. The essay was, moreover, emblematic of Emerson's turn away from the unbridled self towards a self chastened by discipline and responsibility. Given the exigencies of the war and Emersori's vociferous support for the cause of the North, the authority of manners, discipline and the social self became absolutely necessary.

${ }^{27} J o h n$ Dunn, "The Identity of the History of Ideas," Philosophy 43 (April 1968): 85-1 16; Quentin Skinner, "Meaning and Understanding in the History of Ideas," History and Theory 8 (1969): 3-53.

${ }^{28}$ This point is strongly argued, although without reference to "Social Aims," in George M. Fredrickson, The Inner Civil War: Northern Intellectuals and the Crisis of the Union (New York, 1965), 39-40. 
James composed "On a Certain Blindness" between 1896 and late 1898.29 The initial impetus for the development of an essay reflecting upon our blindness to the diversity of experience may well have come from James' impassioned reading of Tolstoy in the summer of 1896 . The power and humanity of Tolstoy's vision, according to James, "haunts me as nothing literary ever haunted me before." 30 But the essay's genesis and, more importantly, its message were also structured by James' growing concern with America's increasingly imperialistic spirit and activities. ${ }^{31}$

In late 1895 James had been angered, appalled and frightened by the jingoism elicited in the United Stätes in response to President Grove: Cleveland's bellicose remarks on the Venezuelan crisis, a crisis which revolved around a boundary dispute and brought forth a range of Anglophobia and whiffs of war. ${ }^{32}$ To James the dispute and its accompanying warlike sentiments smacked of primitive, dangerous, irrational instincts, a theme he would later develop and seek to resolve in his famous essay, "The Moral Equivalent of War." ${ }^{33}$ Within the few years following the tempest-in-a-teapot Venezuelan crisis, James' worst fears were to be realized as America became engaged in the SpanishAmerican War. James' opposition to that war, principled and activist, is well known, but it coincides neatly with his composition of "On a Certain Blindness." The sentiments he registered in opposition to the conflict were elucidated in the essay.

In a spate of editorials, letters and speeches, James placed economic rivalries and territorial demands secondary to the desire to dominate as motives for the Spanish-American War. James argues that the blindness of nations to the rights and inner experiences of other nations lay at the heart of the dispute. The United States, James contended, had allowed ambition, thoughts of destiny, and "crude and barbaric patriotism" to override the rights of other nations. ${ }^{34}$ Americans, for example, sought to impose their assumptions and wills upon the Filipinos. How, he asked, could we be so blind to the rights of the Filipinos, to "the attempt of a people long enslaved to attain to the possession of itself, to organize its laws and gov't, to be free to follow its internal destinies according to its own ideals." "35 In an impassioned letter to the Boston Evening Transcript

${ }^{29}$ See the editorial notes to James, Talks to Teachers, 243.

${ }^{30} \mathrm{~W}$. James to Theodore Flournoy, 30 August 1896, LWJ 2:48.

${ }^{31} \mathrm{~A}$ detailed analysis of James' anti-imperialism may be found in Robert $\mathrm{L}$. Beisner, Twelve Against Empire: The Anti-Imperialists, 1898-1900 (New York, 1968), 35.52.

${ }^{32}$ See the letters and commentary in LWJ 2:26-32.

"James, "The Moral Equivalent of War," in Essays in Religion and Morality, 162-73.

34Perry, The Thought 2:310-11.

351 bid., 310. 
on March 4, 1899, James literally employed the sentiments and language of "On a Certain Blindness" to rally the anti-imperialist cause and to excoriate the war party. Our leaders failed to understand, he repeated, the Filipinos' inner motivations for freedom. We were unable to empathize with them. We treated them "as if they were a painted picture, an amount of mere matter in our way. They are too remote from us ever to be realized as they exist in their inwardness." 36

"On a Certain Elindness" transformed the Filipino inio a North Carolina squatter, but the message remained the same. We must respect the inner experiences of others and not seek to impose our assumptions and experiences 'ipon them. The muting of the specific context of James' antiwar remarks in "On a Certain Blindness" was necessitated by the medium of public philosophy. It separated his obvious and impassioned diatribes against American imperialism from his implicit, yet still powerfully intentioned, utterances of public philosophy; he sought in. "On a Certain Blindness" to render perennial, yet still powerful, the problems and solutions elicited by the specificity of the Spanish-American War.

The practice and exposition of public philosophy was a multifaceted enterprise for both Emerson in "Social Aims" and William James in "On a Certain Blindness." Entered into because of per:onal requirements and the needs of the American public for guidance of a generalized sort, the arena of public philosophy also allowed its practitioners to address the everlasting question of the relation between self and society. Yet the intentions of public philosophers such as Emerson and James were also narrower; they sought to have an influence, in an implicit manner, upon the social perceptions and actions of their listeners. While much of their discourse tended, as Santayana suggested, to make reality palatable to middle-class audiences and at the same time offer hope and affirmation, public philosophers Emerson and James raised questions and offered generalized solutions to deep and thorny social problems. Within these assumptions, requirements and goals, Emerson and James wore the mantle of public philosopher. 